\title{
STUDIES OF CHANGES IN INSTANT VALUE OF EEG TO AUDITORY STIMULUS
}

By

$\mathrm{K}_{\mathrm{AORU}}$ YAMAMOTO and Yoshumiro KOYAMA

From the Department of Oto-Rhino-Laryngology, Faculty of Medicine, Ōsaka City University

The frequency analysis of the changes of EEG to the auditory stimulus was carried out, to study if the method can be applied clinically to the objective audiometory. In recording the changes in the instant value of EEG to the sound, a limit sound level to which the changes were recognized (threshold), and the relation to the background activity (especi. ally the stages of natural sleep) were observed.

The bipolar electrode was implanted chronically in the Vertex of rabbits. The stimuli were the pure tones with the duration of 5 seconds and a minimum of 30 seconds was allowed to elapse between the stimuli.
The frequency range with some changes in the instant value to the tones at the lower intensity was mostly $9 \mathrm{c} / \mathrm{s}$, especially $7 \mathrm{c} / \mathrm{s}$ less, and the percentage of the positive changes was as below, highest in the drowsy stage and lowest in the deep sleep.

But the considerable percentage of occurrence of the false-positives required the presentation of the number of same tone, making accuracy not posible.

The results lead the author to conclude that this method is not suitable for human objective audiometory.

\section{音刺激に対する非特異瞬時值脳波変化の検討}

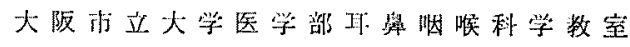 \\ 教授 山本馨・大学院学生 小出出義 裕
}

\section{緒言}

1938 年, A.L. Loomis, et al. ${ }^{1)}$ が, 初めて睡眠時に 音刺激によつて高電位の非特異波が大脳皮質全般に出現 する (diffuse non-specific wave) ことを見出し，これ を“disturbance pattern”と名付けた。 その後，H. Davis et al. 2) 3)(1939) はこれを K-complex と命名し た. Gibbs（1946）は睡眠時の非特異脳波变化が診断的 な価値を有することを報告し，L.G. Doerfler 4) (1948). R.E. Marcus et al. 5) (1949) 户 R.E. Marcus ${ }^{6)}$ (1951) らが脳波变化を聴力測定に利用してから，脳波变化を用 いた聴力測定が注目されるようになつた. R.E. Marcus b)(1951), P. Passouant et al. ${ }^{2}$ (1952), E.R. Perl et al. 3) (1953), L.G. Doerfler et al. ${ }^{9)}$ (1954), C.W. Simon et al 10)(1956), A.J. Derbyshire et al. 11)(1956), A.J.
Derbyshire ${ }^{12}$ (1958), F. B. Withrow et al. 13)(1958), 阿部 ${ }^{4}$ （1954）らの数多くの人によつて音刺激の脳波 に及ぼす変化や䦪值の決定が論じられた。一方，K． Mimura et al. 16)(1962)により脳波の average timepattern 及び average frequency-pattern を求めること により，音刺激にたいする脳波变化が解析されたが，こ の方面の周波数分析的研究は少い。

そこで今回は，非特異脳波变化の周波数分析を動物を 用いて行い，人間の脳波聴力検查へ適用し得るか否かを 検討した.

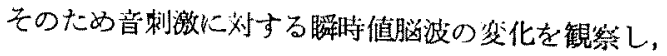
更に背詈脳波の機能レベルとくに自然睡眠との関係につ いて检剧した。 


\section{実駼方法}

体重約 $2.5 \mathrm{~kg}$ で，外耳道正常及び鼓膜穿孔のない白 色カイウサギ（以後，家鬼とする）を用い，Vertex に 電極を掩入した．この皮質電检は直径 $1 \mathrm{~mm}$ の真鍮ネ ジ双極として 2〜3mm の間隔で植云み，長期間存置 する，いかゆる慢性電極である．脳波の記録は電極挿入 の8〜10日後より始めた．実験室は防音及び電気的に シールドされた暗い部屋で，東芝の Audiometer (ST2033A）の端子に気導レシーバー（インピーダンス= 8囚）を連結して，これを家鬼の外耳道深く㨉入した後， 湿綿花を外耳道に㨉入して音量の損失を可及的に防止し た.

12 素子脳波計，周波数分析器及び Selector Box（三 栄測器製) を用い，脳波並びにその瞬時値を同時に記録 した．使用した純音の 周波数は $500 ， 1000 ， 2000,4000$ 及び $8000 \mathrm{c} / \mathrm{s}$ で, 刺激時間は 5 秒, 刺激閒隔は最小 30 秒とし，音刺激及び 刺激遮断時の 瞬時值变化を 観察し た。をた反復せる音刺激に対してその反応性ができるだ け低下しない上うに，純音の周波数，強度 $(\mathrm{db})$ ，刺激 間隔及び刺激耳側を適宜变化さ地心。

\section{実 験 成樍}

1) 音刺激に対する瞬時值变化出現率とその分析周波 数域.

瞬時値の分析周波数帯は第 1 帯 $=2 \sim 3 c / s \quad(=(1)$ ), 第 2 帯 $=4 \sim 5 \mathrm{c} / \mathrm{s}(=(2))$, 第3 帯=6 7c/s（=(3)，第 4 帯 $=8 \sim 9 \mathrm{c} / \mathrm{s}$ (=(4) で，それ以上の带 (band) の周波数 は $10 \sim 1 \mathrm{lc} / \mathrm{s}, 12 \sim 13 \mathrm{c} / \mathrm{s}, 14 \sim 15 \mathrm{c} / \mathrm{s}, 16 \sim 17 \mathrm{c} / \mathrm{s}, 18 \sim 19$ $\mathrm{c} / \mathrm{s}, 20 \sim 21 \mathrm{c} / \mathrm{s}$ 及び $23 \mathrm{c} / \mathrm{s}$ 以上である.

脳波を構成している各周波数成分の瞬時值をみると， 音量が $55 \mathrm{db}$ 以下では大部分は $9 \mathrm{c} / \mathrm{s}$ 以下の周波数域比 おいて比較的明らかな変化が認められた。

この瞬時値变化の分析周波数带数之その出現頻度之の

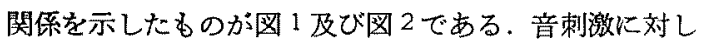
て瞬時値变化の最も出現し易い任意の帯 $(2000 \mathrm{c} / \mathrm{s}$ では 多くは (3) $=6 \sim 7 \mathrm{c} / \mathrm{s}, 500 \mathrm{c} / \mathrm{s}$ では多くは (2) $=4 \sim 5 \mathrm{c} / \mathrm{s}$ で ある）ひとつについて，その瞬時値変化出現率を調べた 場合を横軸の值 1 で示し, この帯とその变化が 2 番目に 出現し易い任意の帯 $(2000 \mathrm{c} / \mathrm{s}$ では多くは (2) $=4 \sim 5 \mathrm{c} / \mathrm{s}$, $500 \mathrm{c} / \mathrm{s}$ では多くは (3)=6 7c/s である) とを加光た二 つの帯について，その瞬時値変化出現率を調べた場合を 横軸の值 2で示し，これと同じょうにして観察する带を 瞬時値変化の出現し易いものから順次一個つつ增して 行き，9c/s 以下の帯でその出現率を調べた場合を横軸

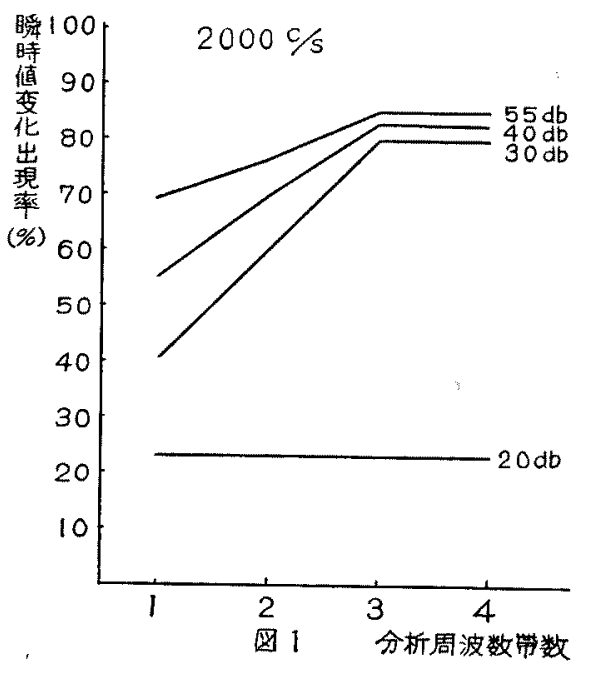

\begin{tabular}{|c|c|c|c|c|c|}
\hline \multicolumn{2}{|c|}{ 全速数 } & 1 & 2 & 3 & 4 \\
\hline \multirow{4}{*}{ 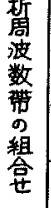 } & 20 & (2) or (3) & (2) (3) & (1) (2)(3) & \\
\hline & 30 & (2) or (3) & (2) (3) & (1) (2) (3) & (1)(2)(3)(4) \\
\hline & 40 & (3) & (2) (3) & (1) (2) (3) & (1)(2)(3)(4) \\
\hline & 55 & (3) & (1) (3) & (1) (2) (3) & (1)(2)(3) \\
\hline
\end{tabular}

表

の值 4 で示した，縦軸には音刺激に対する瞬時值变化出 現率を\%で表わしてある。なお，背景機能のレベルは 浅睡眠相である。

ある家鬼では，図1に示されているよ5に2000c/s に扮いて $20 \mathrm{db}$ を30db に上げると反応の出現率の最大 值は $23 \%$ から $80 \%$ に上昇した。音量を上げるとその出 現率は高くなる傾向が認められた，選んだ分析周波数 帯の数と瞬時値变化出現率との関保をみると，30，40 並 びに $55 \mathrm{db}$ では帯数3でその出現率は最大に達してお。 り，その時の選んだ周波数帯は表 1 に示したように(1) (2) 及び (3) 即ちその分析周波数域は $7 \mathrm{c} / \mathrm{s}$ 以下である. しかし，帯数を4つ選んでもその出現獄は本例では全く 変つていない

また別の家鬼では，図2に示されているよ5に500 c/s でも音量を20から30db に上げるとその出現率の最大 值は32\%から70\%に上昇する，40 及び $55 \mathrm{db}$ では带数 3でその出現率は恬よ゙最大（点B）に達して抢り，選ん だ周波数帯は表 2 に示す如く，やはり(1)，(2) 及び (3) 即ちその分析周波数域は $7 \mathrm{c} / \mathrm{s}$ 以下であり，带数を 4 つ 選えでるその出現率は殆ど変っていない，しかし，30db 


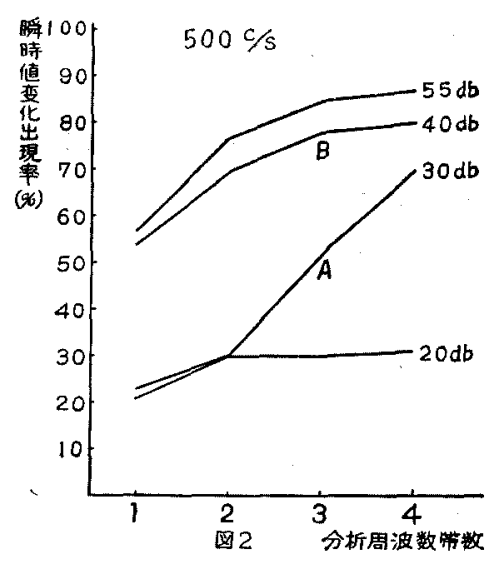

\begin{tabular}{|c|c|c|c|c|c|}
\hline \multicolumn{2}{|c|}{ 带制 } & 1 & 2 & 3 & 4 \\
\hline \multirow{3}{*}{ 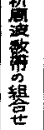 } & 30 & (3) & (1) (3) & (1) (2) (3) & (1023)(4) \\
\hline & 40 & (2) & (2) (3) & (1) (2) (3) & (1)(2)(3)(4) \\
\hline & 55 & (2) & (2) (3) & (1) (2) (3) & (1)(2) (3)(4) \\
\hline & & & 2 & \multicolumn{2}{|c|}{$\begin{array}{l}\text { (1) }=2-3(q / s) \\
=4-5 \\
\text { (3) }=6-7 \\
=8-9\end{array}$} \\
\hline
\end{tabular}

では带数3でその出現率は $52 \%$ (点 A) を示し, 帶数 4で最大に達している. 点 A と B とについて $\mathbf{t}$ 检 定を行らと， $\mathrm{t}=1.3<1.96$ であり，これらの間に有意 の差のないことを示している。

2）背景脳波の機能レベルとくに睡服の時期と瞬時值 変化出現率との関係.

背景 脳波の機能 レベルを安静 覚醒期（ar），傾眠期 (dr), 浅睡眠相 (s), 及び深睡眠相（sd）飞分けた.

種ふの周波数純音に対する瞬時值変化出現率が，背景 脳波の機能レベルとくに睡眠の時期によつてどのよ5に 変化するかをみるため図 3,4,5 及び6を作製した．今回 は音量として 30db のものを用いた。これらの図の縦軸
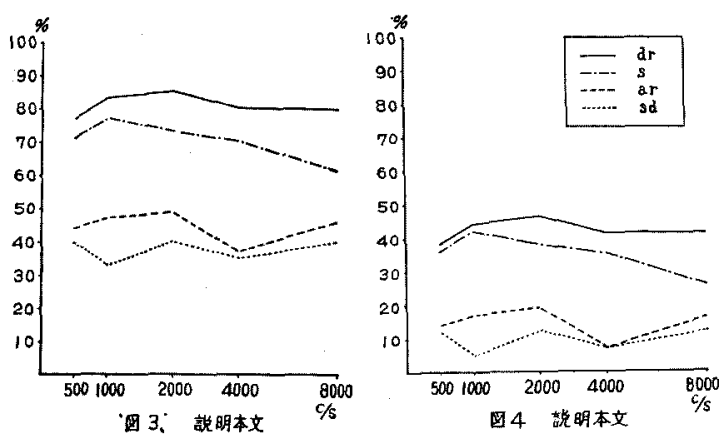
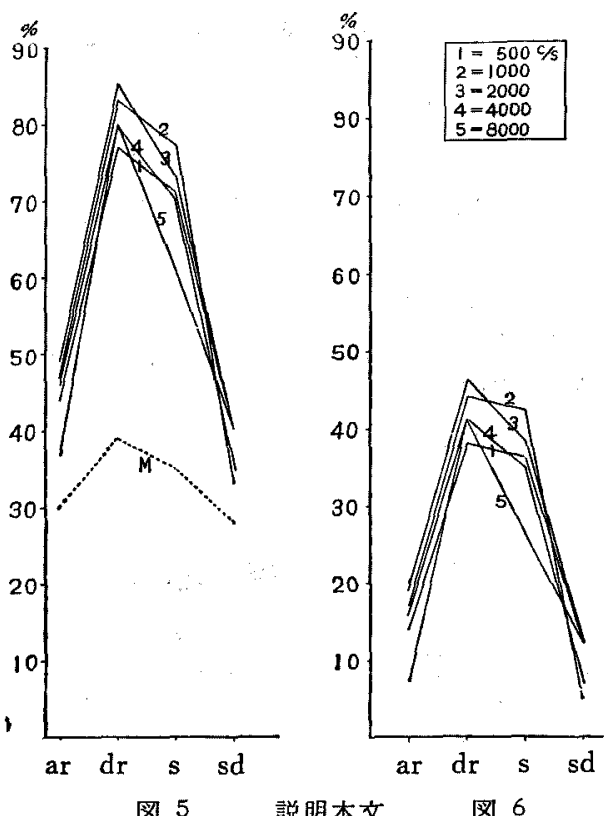

図 5

説明本交

図 6

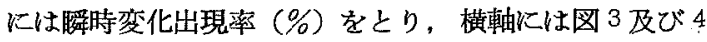
では音の周波数を，図 5 及び6では背景脳波の機能レべ ルをとつてある.これらによると傾眠期においては，音 の周波数に対する瞬時值变化出現率は最る大きくなり， 饮いで浅睡眠相，安静覚醒期そして深睡眠相と綕いてい る. 傾眠期及び浅睡眠相では 1000 あるいは $2000 \mathrm{c} / \mathrm{s}$ に 拉ける変化出現率は比較的高くなつている（図５及び 6). 背景脳波の機能レベルが傾眠期を経て浅睡眠相へ 移行するにつれてその反応の出現率は漸次低下する㑯向 がありまた $8000 \mathrm{c} / \mathrm{s}$ では急に低下する，更に浅睡眠 相から深睡眠相に入ると変化出現率は急公配を描いて低 下するのが認められた。

瞬時值は脳波の僅かの 変化に 対して 鋭敏に変化する が，そのために瞬時值の背景細波の動摇が，音刺激によ つて扎こつた瞬時值変化と愦認されることも考えられ るそここで，音刺激を与えないで marker のみを記録し てみると，偶々瞬時值に変化が羿められる（以下，偶発 変化と呼ふ）頻度 (20 数回中の) は図 5 の点線 (M) て 示されているように。背景脳波の機能レベルによつて異 なり， dr に执いては最高くなつている。

従つて，それぞれの背景脳波の機能レベルに扎いて， 観察上の変化出現率 (図 3 及び 5 ) から偶発变化の出現 率を差し引いたるの（図 4 及び6）が，真に音刺激代対 する変化出現率であると考えられる。 


\section{考按}

閖值程度の音量では脳波の変化は明らかでない場合が 多く，しかる不安定であるから一回だけの結果からその 変化の有無を決定することはできない，従つて同一の刺 激を何回か繰り返して与皇なければならないこの際， 溤れ (habituation) といら問題がおこつてくる。この ような現策を避けるために，音刺湤方法に变化をもた せ，できるだけ単調にならないようにした，即ち音周波 数，音量，刺激間隔並びに刺激耳側を可及的に变えて， 各々の音の新奇性（novelity）を保つた。これについて は, F.B. Withrow et al. ${ }^{13)}$ (1958), A.J. Derbyshire et al. 11) (1956), M.E. Chafetz et al. 16) (1954), 及び P. Passouant ${ }^{7}$ (1952) らも同じような方法をとつている.

成績の項でる述べたよらに，一般に 7c/s 以下の分析 周波数域でその出現率は注ざ最大に達し，それ以上の周 波数帯を選んでる，その出現率は殆ど变らなかつた。従 つて判定に際しては，分析した瞬時值の周波数带の全部 を観察する必要はなく，(1)，(2) 及び (3) 即ち 7c/s 以下 の带を観察す扎ばよいと考えられる。また图2に故い て，40及び $50 \mathrm{db}$ では帯数 $3(7 \mathrm{c} / \mathrm{s}$ 以下) でその出現 率が最大となり，30db では昷数 4 ( $9 \mathrm{c} / \mathrm{s}$ 以下) で最大 となつているが, 点A と B は $\mathrm{t}$ 検定を行つても有意 の差は認められなかつた。このことは一般に 7c/s 以下 の分析周波数帯を観察すればよいが，時にその出現率が 低い場合には 9c/s 以下の周波数带老䘽察すればよいと いらことを示している.これらの分析周波数带に执いて も，なお出現率が低い場合には更に高い周波数帯も観察 する必要があると思われるここように，閾值眭度の音 刺激によつておこる脳波の変化は大部分は 9c/s 以下と

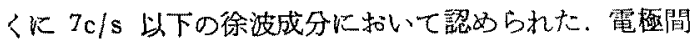
の距離が大きくなると 5〜7c/s の同期型のパタンが現 われ易くなる傾问が諗められた。

K. Mimura, et al. ${ }^{16)}$ (1962) は人間 (adult) で, 60 〜70db のペル音, 10 秒間の刺激で単醇誘導したときの 脳波变化を分析し，自己相関図及びスペクトル密度を観 察した，それによると，対昭では $10 \mathrm{c} / \mathrm{s}$ にピークがみ られるが，音刺澋により，圭れはや>低い周波数にずれ るとい5. そして頭頂部と後頭部では約 $11 \sim 12 \mathrm{c} / \mathrm{s}$, 頭 頂部と前頭部では 6〜7.5c/s の周波数に小さいピークが みられると報告している．このように主に $10 \mathrm{c} / \mathrm{s}$ 以下 の周波数成分が变動していることが知られる。

背景脳波の機能レペルに上つて，音に対する脳波上の 反応性が異なるといらことは既に知られている。ことに
睡服の時期によつてその反応性がどのように变るかとい らことが問題である。

敌物の睡眠に閁して大熊 ${ }^{17)}$ (1962)，山1本 18) (1962) らの報告があり，いず扎皮質及び皮筫下部の脳波上眼 球運動，巧觔及び四肢の筋電図，呼吸及び心電図などを 同時描記して研究を行つている，睡眠の段階について

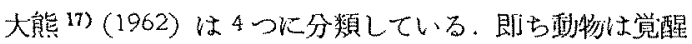
し，皮質波は主に低振幅速波，海馬には $4 \sim 5 \mathrm{c} / \mathrm{s}$ の律 動波が出現する A 期 (覚醒期)，動物が入眠の姿茄を とり，皮質波には 6 12c/s の紡鉭波，海馬では律勤波 が清失して散発性鋭波，不規則な徐波，速波が混在する ところの $\mathrm{S}_{1}$ 期 (䎬眠 1 期)，動物はかなり深い睡眠状 態にあり，皮質には紡鉦波とともに高握幅徐波が出現 し，海馬にも同様の高振幅徐波が出現する $\mathrm{S}_{2}$ 期（睡眠

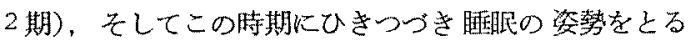
が，皮質には低振幅速波が出現し，海焉には覚醒時の律 動波よりも周期の速い 5 8c/s の規則正しい律動波 連続的に出現する時期即放 $\mathrm{S}_{\mathrm{A}}$ 期 (activated sleep) の四つである。

また山本 ${ }^{18)}$ (1962) は動物が活動的な覚醒時の体姿か ら徐々に弛緩した睡眠時のそれに移行するにつれて，新 皮質及び皮質下部の脱同期的ハタン及び海馬律動波は崩 れて，紡鍾波群発や徐波群が隹位となる。これにひさつ ついて，動物は深睡眠期と京溙の扡緩した体勢のま〉で あるが，海馬律動波が発現して，新皮質や皮質下部に低 振幅速波化のパタンががり安定して持続する。これら 一連の脳波を與奮，覚酫，安静，傾眠一浅睡眠，深睡眠 及び賦活睡服の6水準に分けた。

家鬼に和いても，自然睡眠へ移行する一連の脳波パタ ソは知筧運動領野では低振幅速波，Vertexに执いては 一般に 5 7c/s の同期型のパタン，海馬では $5 \sim 7 \mathrm{c} / \mathrm{s}$ の海馬律徽波が出琶し，呼吸の促進している時期から， 次第に高振幅の不規則な徐波が現われるよらになり，呼 吸が緩徐になるのが恋められた。更に，これにひきつづ いて脳波上には党醒型のハタタンが出現するが，この際 呼吸の促進はみられなかつた。こタは賦活睡眼様の状態 と考えられる。睡眠の深さは眇波パンだけでなく，睡 眠随伴現象との綜合的な結果から判定すべきであるが， 現在一般に睡眠の樑さの示殹として脳波が不可欠と考え られているのは，朝比奈 ${ }^{19)}$ (1962) に上ると睡眠時脑波 のパタンはその大すしにおいて䐺服の相とよく刘応する からであるとい5，本史駼に扣いては背累脳波のレべル を脳波パタンから分類した。 
家雨に扎いて㒃活腄眠様のパタンが認めら孔ること は前述した通りである。い和る賦活睡眠（activated sleep) は Dement 20) (1958) により名付けられたるの で，その後 Jouvet ${ }^{21)}$ ら (1961) Kよつて動物（主に 猫）にも同樣の睡眠相加認められ，paradoxical phase (p.p.)と西壮れた。朝比奈 ${ }^{22}$ (1962) b家鬼の自然睡眠 中に扎い p.p に相当する相を認め，また彼は家鬼に 薬物を投与することによつて人為的に p.p の状態を出現 さ过ることができると報告している。

安静觉醒時では瞬時值変化出現率が低いことは既に述 ベたが，背器脳波が賦活睡眠様パタン現わしていると さにも，音にたいする変化は非常に認め難かつた。大熊 17）(1962）《睡眠の各時期に中脳網様体や他の脳部位に 高頻度電気刺激を和こない，脳波的及び行動的覚醒星搨を 湘定すると， SA 期に和いて覚酒星間值が最も高く，最も 眠りの深い $S_{2}$ 期上りる眠りから觉めにくいという。 また山本 ${ }^{18)}$ (1962) は賦活睡眠期は睡眠の深度からいら と，かなり浅いが，行動の筧醒間は深睡服期に比べて著 しく上年しているという，一方，朝比奈22)(1962) は人 間の p.pでは，覚醒に近い脳波像にありながら音刺激に よる覚醒は脳波，GSR，行動のいずれにも起り難いと指

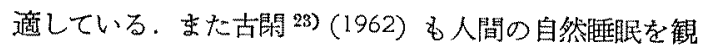
察し，逆説相では睡眠深度はかなり浅い子のから深いる のまで色々であるが，全般的に相当深い上体験されるも のが多いと述べている。

このよらに，賦活睡眠に持いてはその深度といら観点 からみると単純に決め難いが，反応の䦪值はかなり高い と考点られる。

閖値程度の音量では瞬時值に於いてもその变化が分か り難いことが多く，真に音刺激によつて抗こた変化 と背景脳波の動摇によるそれとは，はつきり区別するこ とが難かしい場合が多からた。しか子前述したように marker の文記録した時に扚こる偶発変化がかたりの 頻度に認められた. 従つて音刺激に対する顊察上の变化 出現率から午の偶発変化の出現する頻度を差し引いた方 が無難であると考光る。

F.B. Withrow et al. 13) (1958) は人間における垁験 で, 脳波区灾の false positive occurrence は小さく， 僅か 5\%と記载しているが，本実験では図5に示与如く 偶発変化の出現頻度はかなり高索で，しか子不安定であ り，また背景脳波の機能レベルによつて異なり，ことに 傾眠期に扣いて高かつた，図1及び図2でみたように， $20 \mathrm{db}$ では 2000 及び $500 \mathrm{c} / \mathrm{s}$ ともにその瞬時変化出現率
は偶発变化の旮れと区別がつかない従つて艺の䦪值は $20 \mathrm{db}$ と $30 \mathrm{db}$ との間にあると考えられる。このよらに 偶発变化の出現する頿度が高いのは，瞬時値の背景脳波 は一般に非常に動摇し易く，不安定であることに起因し ていると考元られ，更に一連の背景膍波のパタンの経過 を多ていると，その裂化する時点がある程度推測される ために，その㭙点に音剌激を与支る傾向がある上うに思 われる，従つて，できるだけその出現率の精度を高めよ らとすると相当多くの音刺激回数を必要とする，その回 数が多くなるにつれて㓮れの問題が重要となり，テスト

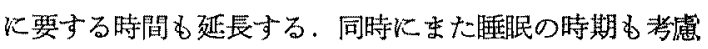
しなければならない，從つて実用性は少くなる。これら のことを考之合せると, 陻床的に脳波聴力検查に利用す ることは現在の段管では適当でないと考える。

G.V. Gershuni ${ }^{24)}$ (1945) は爆風による傷書 (blast injury) の後に音刺激が感知されないことがあるが，こ れは求心性インパルスが中枢神経系に到達していないこ とを埝味するあのではないことを述べている。多くの postconcussional deafness の患者で惊刺激は知覚さ れないが, cochleo-pupillary reflex や側頭部の action potential などの客観的な反応は生じるとい5. 従つ て，これらの反证 imperceptible “sensory” stimuli (知覚されない「感覚下」刺激)に刘する反応であると いら。このように音インパルスに郝して客観的な反応が 生じていても聞えないことがある，位つて音刺激に刘す る脳波の変化上，それが噹筧として知筧されたか否かと の間の関倸は，今な䋇問題とされているところである。 この閒題に対する有用な指標となるものの一つは条件反 射であるといわれている、今後，機会があればこの点に ついて検討したいと考觉る。

\section{結語}

非特異脳波变化の周波数分析が人間の脳波德力検查に 適用できるか否かをみる目的で，動物奉験を行つた。白 色カイウサギ（き）のVertex に慢性電極を插入し， 純音刺激に対寸る瞬時值脳波を観察し，更に背景脳波の 機能レベルことに睡眠の時期との閔係について検討して 次の結果を得た。

1) Vertex では大部分は $9 \mathrm{c} / \mathrm{s}$ 以下の 分析周波数域 において比較的明らかな变化が認められたが，一般にこ の中で瞬時值变化出現率が高く, 観察する必要のある分 析周波数域は $7 \mathrm{c} / \mathrm{s}$ 以下であった。

2) 瞬時値変化出現率は傾眠期に和いて最も高く，浅 睡眠相，安静覚醒期及び深睡眠相の順に低くかつた，樑 
睡眠相にひきつざいて賦活睡眠様のバタンを現わすこと があつた，この際，音剌激にたいする変化は非常に認め 難加つた。

3）本法を臨林的に脳波聴力検楚に適用することは現 在の段階では適当でないと考える。

\section{參考文献}

1) Loomis, A.L., Harvey, E.N. and Hobart, G.: Disturbance-patterns in the human EEG with special referece to sleep. J. Neurophysiol., 1:413 430, 1938b. 2) Davis, H., Davis, P.A., Loomis, A.L., and Harvey, E.N.: Analysis of the electrical responce of the human to auditory stimulation during sleep. Amer. J. Physiol., 126, 474 475, 1939. Davis, H.. Davis, P.A., Loomis, A.L., Haraey, E.N., and Hobart, G.A.: Electrical reactions of human brain to auditory stimulation. J. Neurophysiol., $2: 494 \sim 499,1939 . \quad$ 4) Doerfier, L.G.: Neurophysiological clues to auditory acuity. J. Speech. Hear. Disord., 13:227 232, 1948.

5) Marcus, R.E., Gibbs, E.E., and Gibbs, F.A.. Electroencephalography in diagnosis of hearingloss in the very young child. Dis. Nerv. Syst., 10: 170 173, 1949.

6) Marcus, R.E.: Hearing and speech problems in children; obserbation and use of electroenceohalography. Arch. Otolaryng. 53: 134 136, 1951. 7) Passouant, P., Schwab, R.S., Brazier, M.A.B. and Casby, J.: Activation of the EEG, during sleep with regular repetitive sounds every 2 to 10 seco. nds EEG. Clin. Neurophysiol., 4: 382 383, 1952.

8) Perl, E.R., Galambos, R. and Glorig, A.: The estimation of hearing threshold by EEG. EEG. clin. Neurophysiol. 5: $501 \sim 512,1953.9$ 9) Doerfier, L.G. and McClure, C.T.: The measurement of hearing loss in adult by galvanic skin response. J. Speech. Hear. Disord., 19 : 184 189, 1954.

Scimon, C.W. and Emmons, W.M.: EEG consciousness and sleep. Science, 124: 1066 1069, 1956. 11) Derbyshire, A.J., Fraser, A.A., McDermott, $M$. and Bridge; A.: Audiometric measurements by electroencephrography. EEG Clin. Neurophysiol., 8: 467 478, 1956 . 12) Derbyshire, A.J. and $M c$ Dermott, M.: Further contributions to the EEG. method of evaluating auditory function. Laryngoscope, 68, 1:558 570, 1958. 13) Withrow, F.B., and Goldstein, R.: An electrophysiologic procedure for determination of auditory threshold in children. Laryngoscope, 68, II: 1674 1699, 1958. 14) Abe, $S$. Electrical responses of the human brain to acoustic stimulus. Tohoku. J. Exp. Med., 60: 47 58, 1954. 15) Mimura, K., Sato, K., Ozaki, T., Honda, N. and Masuya, S.: On the physiological significance of the EEG changes caused by sonic stimulation. EEG Clin. Neurophysiol., 14:683 696, 1962. 16) Chafetz, M.E. and Cadilhac, J.: A new procedure for a study of barbiturate effect and evoked potencials in the EEG. EEG Clin. Neurophysiol, 6:462 472, 1954. 17) 大熊粌堆：睡眠の

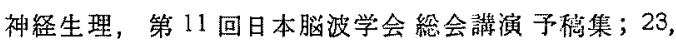
1962. 18) 山本研一：相眠の科経生理, 第11回日本 脳波学会総会講演予稿集；24，1962，19）朝比奈一男：

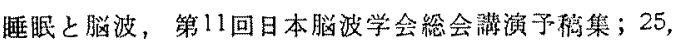
1962. 20) Dement, W. and Kleitman, N.: Cyclic variations in EEG. during sleep and their relation to eye movements, body motility and dreaming. EEG Clin. Neurophysiol., 9:673 690, 1957. 21) Jouvet, M:: The nature of sleep. 188, 1961. 22)

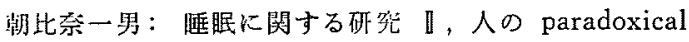
phase (p.p) 和よび reverse paradoxical phase (r.p.p). 日本生理誌 $24 ； 443 \sim 450,1962,23$ ）古閑永之助：

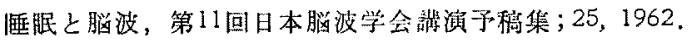
24) Luria, A.R.: Restoration of function after brain injury. Pergamon Press, 7, 1963.

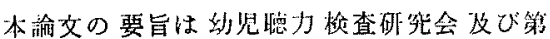

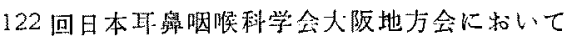
発裴した。

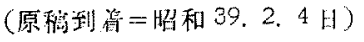

